\title{
Language, education, and power in refugee camps: A comparison of Kakuma Refugee Camp (Kenya) and Thai- Myanmar refugee camps
}

\author{
Hang M. Le \\ International Education Policy, University of Maryland - College Park
}

\begin{abstract}
While there is growing attention to language as a central issue in education for refugees, this policy area still appears to be dominated by an apolitical, technical, and instrumentalist perspective. Through a comparison of language-in-education policies in two refugee camp contexts, Kakuma Refugee Camp in Kenya and the refugee camps along the Thai-Myanmar border, this paper demonstrates how language policies are always deeply political in nature. In refugee contexts in particular, language policies in education reflect and reproduce existing power dynamics that can exclude refugees from decisionmaking processes about their own future. In Kakuma, language issues in education are decided by the international humanitarianism regime based on efficiency and costeffectiveness over the linguistic rights of the refugee community. Even when refugees are in control in the Thai-Myanmar refugee camps, decisions over the language of instruction are still political choices that serve to exclude many people.
\end{abstract}

\section{Introduction}

In the midst of a new global educational agenda that seeks to 'leave no one behind' in equal access to quality education, education for refugee children and youths has emerged as a key area of concern for international humanitarian and development actors (Education Cannot Wait, 2017; Education Commission, 2016; Global Education Monitoring [GEM] Report, 2018). Recent policy discourse and practice in this area also signals a growing recognition that language is a central issue in refugee education, whether in pre-resettlement, post-resettlement, or repatriation settings (Dryden-Peterson et al., 2018; Chopra \& Dryden-Peterson, 2015). However, language policies in refugee education still appear to be predominantly treated as an apolitical, technical issue, where language competency and literacy is simply an instrumental tool to access more education and a better future. This paper is a comparative case study of language-in-education policies in two refugee camp contexts, Kakuma Refugee Camp (Kenya) and the various refugee camps along the Thai-Myanmar border, drawing on a review of the scholarly and grey literature on education in these contexts. With an explicit engagement with power dynamics in language planning in education, this paper highlights how language choices and policies in education are always deeply political in nature.

In particular, in Kakuma Refugee Camp, language issues in education are largely invisible with a de facto language policy that derives from the larger agenda of integration into the Kenyan national education system. These decisions, made mainly by the international humanitarianism regime, point to an apolitical style of policy-making that privileges 
efficiency and cost-effectiveness over the linguistic rights of the refugee community. This in itself is also a political move as it reproduces an unequal power hierarchy with international aid agencies at the top and refugees at the bottom. However, even when refugees are in control of language-in-education policies such as in the Thai-Myanmar refugee camps, decisions over the language of instruction are still political choices that serve to exclude many people. Though the nature of the power elite and their particular agendas differ between these refugee camp contexts, issues of language in education in these contexts are always tied to power, inclusion and exclusion, and contestation over what should be the future for refugees. Given how language cuts across all dimensions of the human experience and the essential role that languages play in empowerment and development, it is important to elevate and prioritize language planning in refugee education and ensure that all community stakeholders are involved in decision-making.

In the next section, I will provide a brief context of refugee education and review how language issues have been discussed in the refugee education literature. This is followed by the methodology section, which includes a description of the two camp contexts. The findings lay out the language issues in education in Kakuma Refugee Camp and then in the Thai-Myanmar border camps. The article ends by discussing the importance of recognizing and prioritizing political deliberation over language-in-education policies in refugee education contexts.

\section{Refugee Education and Language Policies \\ Literature Review Context of Refugee Education}

Distinct from development aid, the international humanitarianism regime is characterized by an emergency and medical approach that seeks to meet the basic physiological needs - food, water, sanitation, and shelter - of human beings caught in situations of active wars, conflicts, and displacement (Malkki, 1995; Pandolfi, 2003; Rajaram \& Grundy-Warr, 2004; Ramadan, 2013). While education has always been in high demand among refugee populations, the provision of schooling has historically been neglected due to its awkward fit with this emergency medical humanitarianism approach favored by refugee assistance agencies (Waters \& LeBlanc, 2005). In a report commissioned by United Nations High Commissioner for Refugees (UNHCR) - the United Nations (UN) refugee agency and main international actor responsible for refugee protection - to chart future steps in policy and programming for refugee education, Dryden-Peterson (2011) observed, "[T]here is little evidence of tangible organizational commitment by UNHCR to guarantee the right to quality education for refugee children and young people" (p. 9). For many years, UNHCR did not have a single education officer. Most humanitarian officers saw education as an area beyond the capacity of the institution, believing that education would invite a false sense of permanence in situations that should only be temporary. It was only at the beginning of the $21^{\text {st }}$ century that education was recognized as a legitimate humanitarian need due to its link to psychosocial wellbeing, with schools becoming seen

as healing spaces that can help refugee children return to the routines of daily life and recover from the trauma of displacement (Waters \& LeBlanc, 2005). 
Thus, for many years, refugee educational policies in countries of first asylum, where refugees await either repatriation or resettlement to other places such as the U.S. or Australia, were quite ad hoc and dependent on the power dynamics in each setting. In many refugee camps, UNHCR dictated that the education system would follow the curriculum of the refugees' countries of origin, due to the belief that the refugee children would soon be repatriated when conflicts at home ended (Waters \& LeBlanc, 2005). However, the reality that displacement is always protracted eventually prompted a shift in UNHCR's educational policy towards promoting 'national integration' into the host countries' education systems (UNHCR, 2012). The rationale of 'national integration' is that the education systems in the host countries would already be established in terms of curriculum, teacher training, accreditation, and consequently would be able to provide a higher quality and more cost-effective education to refugee children. This, of course, ignores the fact that most refugees fleeing conflicts end up in neighboring countries that are also developing nation-states with their own educational issues. However, 'national integration' also appears to be the most favored approach by scholars and practitioners working in the field of education for refugees (Dryden-Peterson et al., 2018; GEM, 2018).

\section{Language in Refugee Education}

The impetus to support refugees' quick integration into national education systems, many of them following languages other than the students' home languages, has once again highlighted languages as a serious educational concern for refugee children and youth. Language barriers and language acquisitions have always been prominent areas of educational research on refugee students in post-resettlement settings (Kanno \& Varghese, 2010; Loewen, 2003; Watkins et al., 2012). In countries of first asylum, language has also been consistently identified as one of the main challenges to educational quality and student achievement (Dryden-Peterson, 2016; Mendenhall et al., 2015).

Despite this recognition of language learning as a significant issue for refugee children and youth, on the whole, existing research and policies in refugee education have rarely addressed the need for explicit language planning and the formation of language-ineducation policies in refugee contexts. This planning would include decisions over which language(s) will be the language of instruction, how they will be taught, or how different languages will be promoted. The default position seems to be to promote learning the language(s) of the host countries, based on a simplistic instrumentalist view that this will have positive impact on refugees' lives by enabling their integration into economies and societies (Ameen \& Cinkara, 2018; Mburu et al., 2004). For example, in the only place where 'language' appears on the UNHCR's Global Education Strategy 2012-2016, it is to discuss 'language training' as one of the key activities to ensure that refugee children will learn better. More recently, the 2019 GEM Report with the theme of migration and displacement once again raises 'limited language proficiency' as one of the main obstacles that refugee students face in trying to integrate into a new education system. This conforms to a meta-framework in language policy-making that only conceives of language-as-problem, where the overarching concern is to solve the minority students' lack of proficiency in the dominant language and promote their assimilation/integration into society (Jong et al., 2016; Ruíz, 1984). 
However, language acquisition is never neutral. It is not just a process of learning the standard grammar, pronunciation, vocabulary, and rules for usage as the functionalists would assume. Rather, language acquisition is wrapped in a hierarchy of values attributed to its speakers, where the 'right' to speak and to be heard is rarely equally shared (Bourdieu, 1991; Norton \& Toohey, 2011). Language choices are also deeply implicated in individuals' sense of self, identities, and communities of belonging. In minority communities in particular, language practices can be a powerful reservoir for solidarity-building, enactment of agency, and contestation of power (Valentine et al., 2008). As such, decisions over language-in-education policies are political choices that should be made after careful deliberation by all community stakeholders, rather than defaulting to a technical solution of teaching refugee's language(s) to facilitate their integration into their new environments. While the political nature of languages and language maintenance in post-resettlement refugee communities has been highlighted in existing research (Perry, 2008), such issues have rarely come up in work within preresettlement refugee camps.

\section{Methodology}

This paper is a literature review of existing studies on education in two refugee encampment settings, Kakuma and the Thai-Myanmar border. The two sites were chosen for this study because both are long-standing refugee camps in the world and have had enough research and knowledge produced about their education systems to enable a comparison of their language-in-education policies, despite the fact that these policies have rarely been the main focus of research in the field.

Kakuma Refugee Camp was established in 1992 in the poor and remote Turkana region of Kenya, where the semi-arid climate and bad soil conditions prevent any agricultural development attempts. Originally established to serve Sudanese refugees, the camp is now home to over 100,000 refugees of 21 different nationalities, the majority of whom are South Sudanese and Somali, though they can also be divided further along ethnolinguistic lines (Lutheran World Federation, 2015). The Thai-Myanmar border camps refer to a collection of nine refugee camps along the border between Thailand and Burma/Myanmar. ${ }^{i}$ By January 2021, an estimated number of 92,000 people still live in nine refugee camps (The Border Consortium, 2021). Two of the camps in the north are predominantly Karenni, while in the other seven camps, the Karen are the majority - both are ethnic minorities in Myanmar. Nevertheless, just like in Kakuma, each camp context is marked by considerable ethnic, religious, and linguistic diversities. Those living in both Kakuma and the Thai-Myanmar refugee contexts are subjected to severe limitation on their mobility and eligibility to work, and conditions of living in the camps are extremely dependent on international assistance.

The sources reviewed include 70 peer-reviewed and grey publications, as well as policy documents, published in English from 1998-2020. I first conducted a database search on Educational Resource Information Center (ERIC) and Education Source with keywords related to the two refugee camps contexts and education and schooling. I also conducted a Google search for the grey literature. Additionally, I drew from the list of references to add to my literature review. These sources were examined for issues of language in 
education for refugee children and youth (if discussed at all), and how decisions about languages are made or not made in each refugee camp context.

As a literature review, this article is limited by its dependency on previous research, which can be dated. Furthermore, it is also restricted by the limited space that other researchers had given to language planning, and my review was often an exercise of reading between and behind the lines. Even so, through connecting various traces and arguments on language issues in previous publications, this literature review brings to the surface a lessdiscussed yet highly important policy area in refugee education.

\section{Findings}

\section{Language-in-Education Planning in Kakuma Refugee Camp}

Although Kakuma Refugee Camp has been running for over two decades, observers have commented that its education system is still barely functional. Within the camp, there are now six preschools, ten primary schools, and one secondary school (Wright \& Plasterer, 2012). This system is mainly managed by a network of international non-governmental organizations (I/NGOs) and led by UNHCR. As of 2014, refugee children are legally allowed to attend government-run schools outside of Kakuma, but due to the costs, in reality only exceptional students are sponsored by NGOs to do so. It has been estimated that nearly half of school-age refugee children and youths in Kakuma remain out of school (Bellino \& Dryden-Peterson, 2018). For those still in school, the severe infrastructural limits mean that the average class size is 147, and in primary schools alone it is 156 (Lutheran World Federation, 2015). This is further compounded by other issues such as low educational achievement, high drop-out rate due to employment or marriage, and lack of training and support for teachers leading to high absenteeism.

When schools were first established in Kakuma Refugee Camp, most refugees and some administrators wanted to follow the Sudanese curriculum (Mareng, 2010). First, following the Sudanese curriculum would prepare the children and adolescents to re-integrate into the education system once they return home to Sudan. Secondly, most of the teachers in the camp at the time had been trained in the Arabic system and did not know either English or Kiswahili to teach the Kenyan curriculum. However, because any hope of finding gainful employment in Kenya would require obtaining the Kenyan Certificate of Primary Education (KCPE) and the Kenyan Certificate of Secondary Education (KCSE), schools in Kakuma Refugee Camp decided to follow the Kenyan curriculum, which also includes their language of instruction policy. Mareng (2010) argued that this decision was highly influenced by UNHCR's preference. In addition to exacerbating the mismatch between students' home languages and the languages of instruction in schools, this decision in effect stripped the already-qualified refugee teachers of the ability to teach, which was also one of the very few ways to earn an income in the camp.

While the official Kenyan language-in-education policy allows for the mother tongue as the language of instruction up to grade 3, in camp settings, refugee children must learn both Kiswahili and English since grade 1. While refugee children originating from Burundi and the Democratic Republic of Congo have prior knowledge of Kiswahili, they 
lack English proficiency and end up being placed in classes with younger children, thus falling behind in age-appropriate academic content (Bellino \& Dryden-Peterson, 2018; Dryden-Peterson, 2016). South Sudanese and Somali children tend to not meet the proficiency level required to do well in schools in both languages. This issue of proficiency is further exacerbated by whether their teachers are capable and/or willing to address the heterogeneous linguistic needs of their children. Kenyan teachers in the camp have been shown to be resistant against shifting the curriculum to accommodate refugee students' needs (Bellino \& Dryden-Peterson, 2018). Refugee teachers can speak more languages but teach exclusively in English, no matter their actual level of English proficiency. Moreover, given the lack of training and support that refugee teachers receive - most have had no more than five days of training - it is no surprise that refugee teachers have expressed difficulties with using their students' home languages to support the acquisition of English and Kiswahili (Dryden-Peterson et al., 2018; Mendenhall et al., 2015).

In this linguistically diverse environment, English has emerged as the lingua franca in education and social settings in general, which is not without the various problems associated with this dominance of a former colonial language (Brock-Utne, 2000). Many NGO programs in Kakuma share a common emphasis on English instruction to meet needs such as women empowerment, communication between community leaders and relevant authorities, professional development of refugee teachers, and out-of-school youths needing to re-enter the education system or obtain jobs (Saucier, 2013; Wright \& Plasterer, 2012). Early childhood education programs also focus on providing early English instruction, which are typically identified by refugees as positive and valuable initiatives (Mburu et al., 2004; Perry, 2008). English is always discussed in a beneficial sense of a neutral language that serves to promote social integration within the camps and the educational achievement of refugee children. For example, an NGO staff noted the importance of English literacy in conflict resolution, "English helps leaders to come together and talk to understand each other, to appreciate one another, and therefore it becomes a tool of reconciliation - a tool of peace" (Wright \& Plasterer, 2012, p. 47). However, anecdotes from refugees have shown how the hierarchy of languages in Kakuma Refugee Camp, with English at the top, fuels rumors about unequal treatment of refugees based on language choices (Perry, 2008). The lack of languages represented in the school system also means that many refugees lack print literacy in their home languages and instead have to rely on English for written communications, which poses quite a challenge for refugees' attempts to protect not only their languages but a sense of normalcy, community, and belonging in what is already a reality of extreme loss and deprivation (ARC Centre of Excellence for the Dynamics of Language, 2017; Perry, 2008).

\section{Language-in-Education in the Thai-Myanmar Border Camps}

In contrast to the Kakuma Refugee Camp, the Thai-Myanmar refugee camps have a relatively well-established education system that is almost entirely managed by the refugee communities themselves (Maber, 2016; Oh \& van der Stouwe, 2008). ${ }^{\text {ii }}$ In the seven predominantly Karen camps, 64 basic education schools, 22438 students, 1005 teachers (Oh et al., 2019). Additionally, in the two Karenni camps in the north, there are also 11 schools. It is generally believed in the refugee community that access to education is equal 
to everyone: everybody who wants to can attend school and receive an education (Thawda et al., 2007). Although the Royal Thai Government officially has overall authority over the education in these camps, they have quite a laissez faire approach to education and leaves educational policy and provision for refugee children to the community education management system. The less salient presence of UNHCR in the border zone between Thailand and Myanmar has also allowed the refugee communities themselves to fill the position of the pseudo-state often assumed by UNHCR (McConnachie, 2012; Oh \& van der Stouwe, 2008). ${ }^{\text {iii }}$ The Karen and Karenni in exile each have their own Education Department which provides standardized educational policymaking in the camps. This non-state, community-organized education system is so strong and well-coordinated that some young people have specifically sought to become refugees and residents in the camps precisely for the educational opportunities offered there (Lee, 2014; Maber, 2016).

Despite the community ownership over the education process in these refugee camps, language still serves as an exclusionary mechanism for many refugee children and youths living here. The education system in the seven predominantly Karen refugee camps use Skaw Karen as the main language of instruction. However, Oh and van der Stouwe (2008) estimated that in three of the camps, only 40-56 percent of refugees are Skaw Karen speakers, 32-41 percent are Pwo Karen speakers, and 12-24 percent are Burmese speakers. In the other four Karen camps, while most residents (between 75 and 88 percent) are Skaw Karen, there is still a significant number of refugees who do not speak this as their mother tongue and are thus more disadvantaged in the school system.

To deal with the language mismatch, in two camps, the Burmese-speaking Muslim community has organized specially designated Muslim schools, which do not provide religious education but rather uses Burmese as the language of instruction. In the other camps, though there are no specific Muslim schools, the Muslim groups there originated from parts in Myanmar where they would have gained bilingual proficiency in both Skaw Karen and Burmese, enough to follow the curriculum. However, the Muslim schools only provide up to Grade 7, and students would then have to transfer back into the Skaw Karen system. Oh, and van der Stouwe (2008) found this to be a significant cause of drop-out, as many students cannot transfer because their Skaw Karen is not good enough. While at the primary level, about 23 percent of all students are Muslim, this percentage drops to only 4 percent at the high school level. Some schools and teachers provide catch-up language classes, but these are only provided on an ad-hoc basis (Oh \& van der Stouwe, 2008).

The role of English in these border camps is also complex. In the early days, most textbooks used in the camps were in English because they were provided by the international donor community. The provision of these textbooks aligned with the emergency approach to humanitarianism, which tries to adopt quick fixes, like already published English-language textbooks, rather than invest resources in textbook development (Oh, 2010). Moreover, the presence of English-speaking international volunteers, as well as the refugee communities' own desires to learn English for better chances in the resettlement process, also drove up the teaching of English in these camps. One of the influential foreign NGOs in the Thai-Myanmar region, ZOA Refugee Care, 
used to be quite active in advocating for more attention toward language-in-education issues as a fundamental dimension of educational inclusion and equity. In their 2007 position paper, ZOA explicitly brought up the issue of language of instruction: "[S]tudents who do not fully understand the language of instruction are excluded from the learning that occurs in school" (Thawda et al., 2007, p. 10). To that end, they were in the process of translating textbooks from English into Skaw Karen as well as assessing the language curriculum and training needs of teachers in bilingual education pedagogies. Unfortunately, however, this NGO had stopped its operations in the Myanmar-Thailand region since 2012, due to a wider trend of international donors disassociating themselves from community organizations in this border zone and redirecting aid towards the Myanmar government (Décobert \& Wells, 2020; Ma Night Awa, 2011).

This recalibration of aid is an effect of the changing political landscapes in both Myanmar and Thailand in the past decade, with other significant impact on education and life in the refugee camps. While in Myanmar, 2010-2020 marked a very gradual process of liberalization and political reforms towards democratization, Thailand has undergone a reverse process with its military coup in 2014. Subsequently, the Thai military began to impose stricter monitoring and restrictions on the refugee camps. Coupled with the reduction in international aid to the camps and the ethnic minority groups at the border, this has led to the gradual dismantling of schooling in the refugee camps, with the students beginning to look towards Myanmar to continue their education (Oh et al., 2019). At the same time, the Myanmar government has indicated some willingness to work with ethnic minority groups to ensure that the children can receive quality education and accreditation. In particular, it has taken the initial steps to introduce mother tongue-based multilingual education, with a clause in the National Education Law in 2014 that encourages instruction in ethnic languages alongside Burmese, "If there is a need, an ethnic language can be used alongside Myanmar as a language of instruction at the basic education level" (Chapter 7, Clause 43).

Nevertheless, language is an ongoing source of conflict and distrust between the ethnic minorities and the central Myanmar government. For example, in 2016, the Minister for Border and Security Affairs made official complaints about how schools run by the Karen Education and Culture Department still used Karen as the language of instruction (Oh et al., 2019). Moreover, discussions between the Karen and the government on the recognition of refugee students' credentials and allowing them into government schools have stalled (Shiohata, 2018). On the other side, recent studies with the Karen education leadership in particular have revealed discontent with the government's expansion of control, with the perception that this is "a deliberate attempt to undermine their community education systems, as well as their ethnic language and identity" (World Education, 2016). From how political and educational negotiations with other ethnic minority groups have gone in Myanmar, language and mother-tongue based education will continue to be a very contested debate with no clear consensus on the role of the ethnic language, the dominant Burmese language, as well as a possibility of English as the lingua franca (South \& Lall, 2016). 


\section{Discussion}

In Kakuma Refugee Camp, language-in-education issues are still very much tied to the need to integrate and assimilate into the status quo that is the Kenyan national education system. Consequently, the education for refugee children in Kakuma Refugee Camp ends up reproducing the same language issues that plague Kenya's education in general, including the disadvantages experienced by students whose mother tongue is neither Kiswahili or English and the troubling ongoing dominance of English that is akin to "the recolonization of African mind," Brock-Utne (2000). In this particular case, however, these language choices do not stem from typical dynamic of the dominant groups' interest in reserving educational benefits only to a small elite (Brock-Utne, 2000). Rather, they were made by UNHCR in their function as a pseudo-state in the context of Kakuma. In this paternalistic role, UNHCR made language and curricular choices that were the opposite of what was originally desired by the refugee community, yet framed them in the neutral, apolitical rhetoric of the need to integrate into Kenya's education system for efficiency.

In other words, in Kakuma's language-in-education policies, we can witness the depoliticization of refugee lives because their situation is supposedly only an 'emergency', an overarching but false logic in humanitarian aid that various scholars have critiqued (Barnett, 2011; Calhoun, 2008; Fassin, 2007; Pandolfi, 2003; Versmesse et al., 2017). This logic of emergency and crisis provides international actors with the moral justification to parachute into conflict situations and engage in certain state-like activities, e.g., tracking and governing the population, delivering services, setting up rules and regulations (Cardozo Lopes \& Novelli, 2018; Pandolfi, 2003). In addition to empowering this transnational regime of international donors, the logic of emergency also works to divest refugees of their right to participate in political discussion and decision-making that affect their own lives. Under the assumption that refugees can only be the voiceless victims, international organizations have often been ambivalent toward attempts within refugee communities to self-organize and engage in their own development initiatives. In Kenya, for example, UNHCR staff had been active in breaking up traditional structures of power in Dadaab Refugee Camp so that UNHCR would remain the pre-eminent governing authority for Dadaab (McConnachie, 2012, p. 36).

In determining that refugee communities in Kakuma should have little voice in making curricular decisions, the international refugee regime operating in this camp context is effectively taking away language as a matter of community deliberation and solidaritybuilding. Curricular choices, including language of instruction, are always intertwined with the inherently political project of determining the collective 'we' of the future (Waters $\&$ LeBlanc, 2005). In other words, this in effect decides the future of refugees in Kakuma for them, rather than with them, as one of integration into the Kenyan society - despite the reality that the Government of Kenya has never indicated an opening to this integration. However, community control of educational policies is not necessarily better in terms of educational equality or a more equal distribution of power in the community, as the case of the Thai-Myanmar refugee camps demonstrate. The Karen-dominated refugee camps follow a standardized Karen curriculum which uses Skaw Karen as the main language of instruction to serve the ideological purpose of promoting Karen and Karenni ethnonationalism and secessionist movements. This has led to the exclusion of other ethnic 
minority groups such as the Burman, the Mon, or the Karen who speaks other languages such as Pwo Karen or Burmese (Oh \& van der Stouwe, 2008). It shows how language-ineducation policies, as well as the education system as a whole, are often driven by a need to produce a new cohesive nation. However, as Oh and van der Stouwe (2008) commented, "The irony is that the 'Skawization' of Karen society in the borderlands and refugee camps resembles aspects of the Burmanization carried out by the military government" (p. 611). This is because the leadership structure within the Karendominated refugee camps is also highly authoritarian and dominated by a small group of Christian Skaw Karen elites; likewise, the leadership in the Karenni refugee camps are not so much representative of the communities but rather of the Karenni government-in-exile (Demusz, 1998).

Yet it is also important to remember that dynamics of power are constantly shifting, and that Karen and Karenni elites also have to manage an imbalance of power against international actors and national authorities. This has been most clearly demonstrated in the period from 2010-2020 with changing trends of support in the international aid community. Prior to 2010, as part of the opposition to the military junta in power in Myanmar, international donors were enthusiastic to support community-organized nonformal education. However, as the government began to pursue democratization reforms, international donors have been diverting resources and support for ethnic groups toward the central government (Décobert \& Wells, 2020; S. A. Oh et al., 2019; World Education, 2016). Ethnic educators and exiled activists on the Thai side of the border have felt a sense of exclusion from the national education reform processes, expressing that their decades of work and expertise in education were being ignored by government and international actors (Maber, 2016). The increasing influence that the Myanmar state now plays in areas previously controlled by the ethnic minorities is raising new questions and contestation over the role of languages in conflict prevention, peace promotion, and education. Furthermore, as the situation in Myanmar deteriorates again with the military coup in 2021, refugees and other ethnic minorities living in the ThaiMyanmar borderland will continue to have to figure out new strategies to survive in constantly shifting states of precarity.

\section{Conclusion}

The two cases examined in this article reveal problematic dynamics of power as manifested through policies on language in education. The case of Kakuma show how language policies are often decided not by refugees but by international humanitarian actors, guided by an apolitical approach toward integration into the status quo that strips refugees of their linguistic rights and agency. On the other hand, the case of the ThaiMyanmar refugee camps reminds us that politicization of these issues in the normative way, through linking language with ideological purposes of building national unity, only reproduces problematic and authoritarian power hierarchies.

An interesting avenue for future research would be to examine actual language use in refugee camps to examine how refugees from diverse settings come together and engage in hybridity and translanguaging practices. They can take an asset-based approach that recognizes the benefits of developing multilingual language capabilities and examines 
how education settings can draw on the strengths of multilingualism to enhance learning for all in a linguistically diverse community. This asset-based approach should also inform more practical efforts and interventions at cooperative language planning in education within the refugee camps, with the goal of promoting multilingualism rather than just the transition of the speakers of the minority languages to the majority language (s) (Jong et al., 2016). One way this can be done is inviting all community stakeholders to facilitated dialogues that are guided by professionals in language-in-education issues, informed by research and local expertise, to deliberate the role of different languages and how they should be fostered in the education system (UNICEF East Asia \& Pacific, 2016). The first step is to resist the invisibility or temptation to turn language-in-education issues in refugee education, into another apolitical, technical problem to be solved. As refugee education research, policy, and practice continues to grow in the coming years, language should be centered as a major issue of concern. Linguistic rights are human rights.

M. Le (Lê Minh Hà̀ng) iv is a PhD candidate in the International Education Policy program at the University of Maryland-College Park. Her research interests revolve around developmenthumanitarian aid to education, policy transfer and global education policies, and education in emergencies.

\section{References}

Ameen, R. F., \& Cinkara, E. (2018). The impact of language learning on internally displaced and refugee resilience. European Journal of Educational Research, 7(3), 529538. https: / / doi.org/10.12973/ eu-jer.7.3.529

ARC Centre of Excellence for the Dynamics of Language. (2017, June 26). Community in Kakuma Refugee Camp inspires linguists. Dynamics of Language. http: / / www.dynamicsoflanguage.edu.au/news-and-media/latestheadlines / article/?id=community-in-kakuma-refugee-camp-inspires-linguists

Barnett, M. (2011). Empire of humanity: A history of humanitarianism. Cornell University Press. https: / / doi.org/10.7591/9780801460616

Bellino, M. J., \& Dryden-Peterson, S. (2018). Inclusion and exclusion within a policy of national integration: Refugee education in Kenya's Kakuma Refugee Camp. British Journal of Sociology of Education, 40(2), 222-238.

https: / / doi.org/10.1080/01425692.2018.1523707

Bourdieu, P. (1991). The production and reproduction of legitimate language. In J. Thompson (Trans.), Language and symbolic power (pp. 43-66). Harvard University Press.

Brock-Utne, B. (2000). Whose Education for all? The recolonization of the African mind. Routledge. 
Bunyi, G. W. (2005). Language classroom practices in Kenya. In A. Lin \& P. W. Martin (Eds.), Decolonisation, globalisation: Language-in-education policy and practice (... ed., pp. 131-152). Multilingual Matters.

Calhoun, C. (2008). The imperative to reduce suffering: Charity, progress, and emergencies in the field of humanitarian action. In M. Barnett \& T. G. Weiss (Eds.), Humanitarianism in question: Politics, power, ethics (pp. 73-97). Cornell University Press.

Cardozo Lopes, M., \& Novelli, M. (2018). Education in emergencies: Tracing the emergence of a field. In A. Verger, H. Kosar-Altinyelken, \& M. Novelli (Eds.), Global education policy and international development: New agendas, issues and policies (pp. 233-254). Bloomsbury. https: / / doi.org/10.5040/9781474296052

Chopra, V., Dryden-Peterson, S. (2015). More than words: Language in the move from refugee to returnee to citizen in Burundi (Harvard Education Publishing Group case study). Harvard Education Publishing Group.

Décobert, A., \& Wells, T. (2020). Interpretive complexity and crisis: The history of international aid to Myanmar. The European Journal of Development Research, 32(2), 294-315. https: / / doi.org/10.1057/ s41287-019-00238-y

Demusz, K. (1998). From relief to development: Negotiating the continuum on the ThaiBurmese border. Journal of Refugee Studies, 11(3), 231-244.

https:/ / doi.org/10.1093/jrs/11.3.231

Dryden-Peterson, S. (2011). Refugee education: A global review. UNHCR, Policy Development and Evaluation Service.

https:/ / doi.org/10.3102/0013189X16683398

Dryden-Peterson, S. (2016). Refugee education in countries of first asylum: Breaking open the black box of pre-resettlement experiences. Theory and Research in Education, 14(2), 131-148. https: / doi.org/10.1177/1477878515622703

Dryden-Peterson, S., Adalman, E., Alvarado, S., Anderson, K., Bellino, M. J., Brooks, R., Bukhari, S. U. S., Cao, E., Chopra, V., Faizi, Z., Gulla, B., Maarouf, D., Reddick, C., Scherrer, B., Smoake, E., \& Suzuki, E. (2018). Inclusion of refugees in national education systems (Background paper commissioned for the 2019 Global Education Monitoring Report, Migration, displacement and education: Building bridges, not walls). United Nations Educational, Scientific and Cultural Organization. https: / / inee.org/system/files / resources / Dryden-

Peterson_Inclusion\%20of\%20Refugees_2018_Eng.pdf

Education Cannot Wait. (2017). Why education cannot wait.

http: / / www.educationcannotwait.org/wpcontent/uploads/2016/05/Why_EC W_one_pager_FINAL.pdf 
Education Commission. (2016). The learning generation: Investing in education for a changing world. The International Commission on Financing Global Education Opportunity. https: / / report.educationcommission.org/report/

Fassin, D. (2007). Humanitarianism as a politics of life. Public Culture, 19(3), 499-520.

Global Education Monitoring Report. (2018). Migration, displacement and education: Building bridges, not walls. United Nations Educational, Scientific and Cultural Organization. https: / / en.unesco.org/gem-report/report/2019/migration

Jong, E. J. de, Li, Z., Zafar, A. M., \& Wu, C.-H. (Vivian). (2016). Language policy in multilingual contexts: Revisiting Ruiz's "language-as-resource" orientation. Bilingual Research Journal, 39(3-4), 200-212. https: / / doi.org/10.1080/15235882.2016.1224988

Kanno, Y., \& Varghese, M. M. (2010). Immigrant and refugee ESL students' challenges to accessing four-year college education: From language policy to educational policy. Journal of Language, Identity \& Education, 9(5), 310-328.

https: / / doi.org/10.1080/15348458.2010.517693

Lee, S. K. (2014). Migrant schools in the Thailand-Burma borderland: From the informal to the formal. Asia Pacific Journal of Education, 34(1), 125-138.

https: / / doi.org/10.1080/02188791.2013.803458

Loewen, S. (2003). Second language concerns for refugee children. In Educational interventions for refugee children (pp. 49-66). Routledge. https: / / doi.org/10.4324/9780203687550-8

Lutheran World Federation. (2015). Rapid assessment of barriers to education in Kakuma Refugee Camp. Lutheran World Federation.

https: / / kenyadjibouti.lutheranworld.org/ sites / default / files / documents / Barrie rs $\% 20$ to $\% 20$ Education $\% 20$ in $\% 20$ Kakuma $\% 20$ Refugee $\% 20$ Camp $\% 20$ Assessment_ $0 . p d f$

Ma Night Awa. (2011, July 27). Refugee education hit hard by severe budget cuts. Karen News. http: / / karennews.org/2011/07/ part-2-the-elephant-and-the-sesame-seedrefugee-education-hit-hard-by-severe-budget-cuts /

Maber, E. J. T. (2016). Cross-border transitions: Navigating conflict and political change through community education practices in Myanmar and the Thai border. Globalisation, Societies and Education, 14(3), 374-389.

https: / / doi.org/10.1080/14767724.2016.1175923

Malkki, L. H. (1995). Refugees and exile: From "Refugee studies" to the national order of things. Annual Review of Anthropology, 24, 495-523. JSTOR. 
Mareng, C. D. (2010). Reflections on refugee students' major perceptions of education in Kakuma Refugee Camp, Kenya. Intercultural Education, 21(5), 473-481.

https: / / doi.org/10.1080/14675986.2010.521392

Mburu, E., Mohamed, M., \& Mwaniki, D. (2004). English language instruction in Kakuma Camp, Kenya. Refugee Reports, 25(4). http:/ / www.idahorefugees.org/uploads/3/8/8/9/38892103/refugee_reports_language_interpretation_in_the_delivery_of_health_care.pdf

McConnachie, K. (2012). Rethinking the 'refugee warrior': The Karen National Union and refugee protection on the Thai-Burma border. Journal of Human Rights Practice, 4(1), 30-56. https:/ / doi.org/10.1093/jhuman/hus005

Mendenhall, M., Dryden-Peterson, S., Bartlett, L., Ndirangu, C., Imonje, R., Gakunga, D., Guchuhi, L., Nyagah, G., Okoth, U., \& Tangelder, M. (2015). Quality education for refugees in Kenya: Pedagogy in urban Nairobi and Kakuma Refugee Camp settings. Journal on Education in Emergencies, 1(1), 92-130.

https: / / doi.org/10.17609/n8d08k

Myanmar National Education Law. (2014).

https: / / www.ilo.org/dyn/ natlex/ docs / ELECTRONIC / 100493/120566/F28507 983/MMR100493\%20Eng.pdf

Norton, B., \& Toohey, K. (2011). Identity, language learning, and social change. Language Teaching, 44(4), 412-446. https:/ / doi.org/10.1017/S0261444811000309

Oh, S.-A. (2010). Education in refugee camps in Thailand: Policy, practice and paucity (Background paper prepared for the Education for all Global Monitoring Report 2011, The hidden crisis: Armed conflict and education). UNESCO. https: / / s3.amazonaws.com/academia.edu.documents/31018221/190709e.pdf?A WSAccessKeyId=AKIAIWOWYYGZ2Y53UL3A\&Expires=1547746273\&Signature =SYG4d5N1zqzTW6mA0VOMieq5\%2BRI\%3D\&response-contentdisposition=inline $\% 3 \mathrm{~B} \% 20$ filename $\% 3 \mathrm{DEducation}$ _in_refugee_camps_in_Thaila nd_p.pdf

Pandolfi, M. (2003). Contract of mutual (in)difference: Governance and the humanitarian apparatus in contemporary Albania and Kosovo. Indiana Journal of Global Legal Studies, 10(1), 369-381.

Perry, K. H. (2008). Sharing stories, linking lives: Literacy practices among Sudanese refugees (Working paper no. 8; Cultural practices of literacy study). Michigan State University.

Rajaram, P. K., \& Grundy-Warr, C. (2004). The irregular migrant as Homo Sacer: Migration and detention in Australia, Malaysia, and Thailand. International Migration, 42(1), 33-64. https:/ / doi.org/10.1111/j.0020-7985.2004.00273.x 
Ramadan, A. (2013). Spatialising the refugee camp. Transactions of the Institute of British Geographers, 38(1), 65-77. https:/ / doi.org/10.1111/j.1475-5661.2012.00509.x

Ruíz, R. (1984). Orientations in language planning. NABE Journal, 8(2), 15-34. https: / / doi.org/10.1080/08855072.1984.10668464

Saucier, M. (2013, December 8). Refugee education in Kenya: Language and encampment policies. Anthropology at Teachers College.

https: / / anthropologytc.wordpress.com/2013/12/08/ refugee-education-inkenya-language-and-encampment-policies /

Shiohata, M. (2018). Education for displaced populations in Karen state, Myanmar (Paper commissioned for the 2019 Global Education Monitoring report, Migration, displacement and Education: Building bridges, not walls). Global Education Monitoring Report.

https: / / www.jica.go.jp/jica-ri / publication/ other/175nbg000010mg5uatt/Background_Shiohata.pdf

South, A., \& Lall, M. (2016). Schooling and conflict: Ethnic education and mother tongue-based teaching in Myanmar. The Asia Foundation.

http: / / 2o2ypr1qd5zx1p10sn21fm2b-wpengine.netdna-ssl.com/wp content/uploads/2016/09/KarenState_SchoolCommittees_FINAL.pdf

Thawda, L., van der Stouwe, M., Naw, S., \& Oh, S.-A. (2007). Having their say: Refugee camp residents and inclusive education (A ZOA position paper). ZOA Refugee Care Thailand.

http: / / s3.amazonaws.com/ineeassets / resources / doc_1_ZOA_Position_Paper_ Having_Their_Say.pdf

The Border Consortium. (2021). Camp population 2021. The Border Consortium. https: / / www.theborderconsortium.org/camp-populations / camp-population$2021 /$

UNHCR. (2012). UNHCR Education Strategy 2012-2016. UNHCR. https: / / www.unhcr.org/protection/ operations / 5149ba349/unhcr-educationstrategy-2012-2016.html

UNICEF East Asia \& Pacific. (2016). Synthesis report: Language education and social cohesion (LESC) initiative in Malaysia, Myanmar and Thailand.pdf. UNICEF East Asia and Pacific Regional Office.

https: / / www.unicef.org/eap/media / 836/ file/Synthesis\%20Report:\%20Langua ge $\% 20$ Education $\% 20$ and $\% 20$ Social $\%$ 20Cohesion $\% 20$ (LESC) $\% 20$ Initiative $\% 20 \mathrm{in} \%$ 20Malaysia,\%20Myanmar\%20and\%20Thailand.pdf 
Valentine, G., Sporton, D., \& Bang Nielsen, K. (2008). Language use on the move: Sites of encounter, identities and belonging. Transactions of the Institute of British Geographers, 33(3), 376-387. https: / / doi.org/10.1111/j.1475-5661.2008.00308.x

Versmesse, I., Derluyn, I., Masschelein, J., \& De Haene, L. (2017). After conflict comes education? Reflections on the representations of emergencies in "Education in emergencies." Comparative Education, 53(4), 538-557.

https: / / doi.org/10.1080/03050068.2017.1327570

Wasike, A. (2018). Student mother tongue usage, preference, and attitudes in Bungoma County, Kenya. Africology: The Journal of Pan African Studies, 11(7), 204-220.

Waters, T., \& LeBlanc, K. (2005). Refugees and education: Mass public schooling without a nation state. Comparative Education Review, 49(2), 129-147.

https: / / doi.org/10.1086/428102

Watkins, P. G., Razee, H., \& Richters, J. (2012). “I'm telling you ... The language barrier is the most, the biggest challenge": Barriers to education among Karen refugee women in Australia. Australian Journal of Education, 56(2), 126-141. https: / / doi.org / 10.1177/000494411205600203

World Education. (2016). School committees and community engagement in education in Karen state. World Education.

http: / / 2o2ypr1qd5zx1p10sn21fm2b-wpengine.netdna-ssl.com/wpcontent/uploads/2016/09/KarenState_SchoolCommittees_FINAL.pdf

Wright, L.-A., \& Plasterer, R. (2012). Beyond basic education: Exploring opportunities for higher learning in Kenyan refugee camps. Refuge: Canada's Journal on Refugees, 27(2), 42-56.

\footnotetext{
i While Myanmar is now the official name for this country, many continue to use 'Burma' because they consider Myanmar an imposition by the military dictatorship.

ii The schools within the Thai-Myanmar refugee camps are part of a larger cross-border and nonformal education network that also include schools in the Karen-controlled territory in Myanmar, migrant learning centers for migrant communities in Thailand's border regions, other informal vocational learning sites, and post-secondary community education programs run by grassroots organizations, women's networks, and NGOs. Many of these educational sites serve de facto refugees from Myanmar who would rather become 'illegal' migrants to the Thai authorities than to be confined within the refugee camps. For more research on migrant education in this region, see Lee (2014), Maber (2016), World Education (2016), Shiohata (2018).

iii This is also a consequence of the Royal Thai Government's policy to keep UNHCR out of this conflict until the late 1990s, in part due to a desire to pretend that this was not a refugee situation.

iv I would like to express my appreciation for the feedback provided by Melanie Baker Robbins, Brendan DeCoster, Jeremy Gombin-Sperling, Paul Vernon, and two anonymous reviewers to help me prepare this paper.
} 